Article

\title{
The Visual Construction of the Umayyad Caliphate in Al-Andalus through the Great Mosque of Cordoba
}

\author{
Susana Calvo Capilla \\ Art History Department, Complutense University of Madrid, 28040 Madrid, Spain; susana.calvo@ucm.es \\ Received: 25 June 2018; Accepted: 27 July 2018; Published: 8 August 2018 \\ check for \\ updates
}

\begin{abstract}
My first exposure to the epigraphic program of the Great Mosque of Cordoba, published in 2001, came from reading an article on the ideological meaning of the decoration and the Quranic citations inscribed in al-Hakam II's addition to the building. In that article, I concluded that the Quranic verses found in the mosque were chosen not only for being a universal proclamation of divine power and praise for the Umayyad dynasty, as proposed by Nuha Khoury in 1996, but also because they clearly fitted in with the particular Andalusi, or rather Cordoban, religious, cultural, and political context in the first half of the 10th century. Most of the inscriptions had been read in the 19th century by Amador de los Ríos, but some of them remained uninterpreted. Given that they were an essential part of the ideological message, it seemed appropriate to revisit the critical reading of the epigraphic program and determine its full meaning. Later, I discussed other architectural aspects of the Great Mosque in which the links to the Andalusi and the eastern Umayyad traditions are a key aspect in understanding why these forms were chosen. Damascus, the eastern Umayyad capital, and to a lesser extent Medina and the Abbasid capitals, became the model for the caliphs of Cordoba. This article proposes to revisit the main architectural and decorative features of the caliphal enlargements of the Great Mosque of Cordoba in order to reflect on the meaning and forms of its epigraphic program.
\end{abstract}

Keywords: al-Andalus; Umayyads; mosque; Cordoba; epigraphy; mosaics; caliphate

\section{A New Scenario for the Umayyads of Al-Andalus}

Following 'Abd al-Raḥmān III's (d. 961) decision to declare himself caliph in 929, al-Andalus became the most important arts and knowledge-based centre in the western Mediterranean, directly competing with the Abbasid and Fatimid caliphates, as well as the Byzantine Empire. The Andalusi caliphs mostly draw inspiration from the works of their Damascus Umayyad ancestors for their cultural and artistic pursuits, but also from the Abbasid caliphate and the Byzantine Empire. All of this, added to the Hispanic pre-Islamic patrimony, allowed them to build their own visual and iconographic identity that would also become apparent in later Andalusi art (as in the case of the Almohads). Hence, contrary to the idea that al-Andalus acted in response to their political rivals, or by imitating eastern patterns, my own analysis of the monuments made me increasingly aware of the independence of the Cordoban caliphate in the search for its own visual and ideological models of legitimisation and reaffirmation.

There were three main aspects of influence. Firstly, the Andalusi Umayyads invoked the authority of the "Well Guided" caliphs and of their eastern and Andalusi ancestors to establish their claim 
as supreme guides and guardians of Sunni orthodoxy ${ }^{1}$. Secondly, and similarly to their Umayyad ancestors and the Abbasid Caliphs, they promoted the sciences and the arts, surrounding themselves with scholars and taking care of the princes' education, following the model of the most learned and prestigious rulers since Hellenistic times. Lastly, the Andalusi caliphs also claimed to be heirs of the Greco-Latin culture and the Roman and Hispano-Visigothic legacies, which allowed them to build their own political, cultural, and visual corpus of knowledge (Calvo Capilla 2014b; König). Those three factors were translated into their main artistic projects: the palace-city of Madinat al-Zahrā and the Great Mosque of Cordoba.

Concerning the last aspect, the reutilisation of ancient building materials has been visible in the Great Mosque from the founding phase in the 8th century. During the enlargement by 'Abd al-Rahmān II, in the first half of the 9th century, reutilised materials were combined with new pieces from the Umayyad workshops. (Figure 1) However, the use of Roman and Visigothic Hispania as a legitimation strategy is not only reflected in the ancient construction materials but also through the revival of classical forms in caliphal art. An example of this can be seen in the mihrab of the mosque, and in the display of Roman reliefs and sculptures in the palaces of Madinnat al-Zahrā'. The palatial library of Cordoba, called by Ibn Hayyān (d. 1076) and the Qadī 'Iyad (d. 1149) bayt al-hikma, would contain works by Aristotle, De materia Medica of Dioscoride, the Etymologies and De natura rerum of San Isidore of Seville, and the History of Orose, among others, some of them translated into Arabic (Capilla 2018a, 2014b).

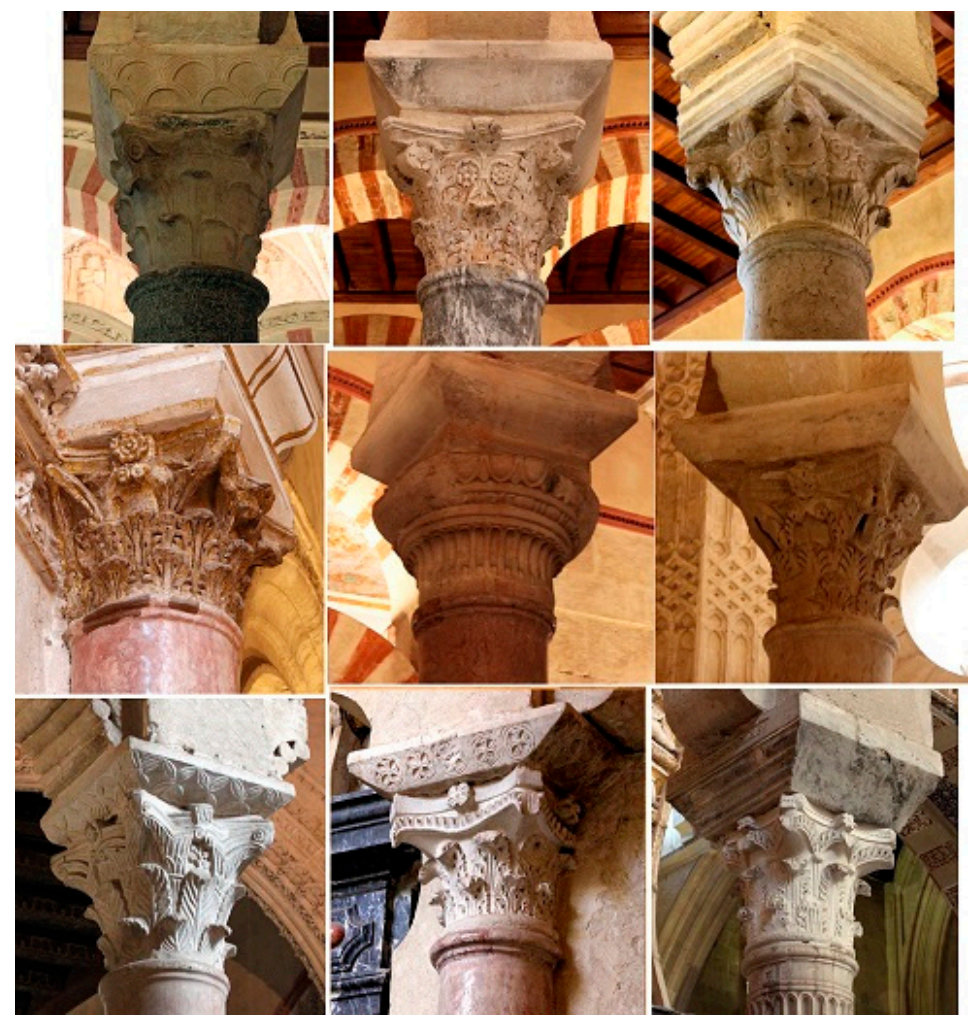

Figure 1. Roman and Visigothic capitals in the 8th and 9th century phases of the Great Mosque of Cordoba. (C) Photos took by author.

1 For further details on the Quranic inscriptions see the following articles: (Calvo Capilla 2001; Calvo Capilla 2010a), as well as a forthcoming article about the inscriptions in the axial nave. Architectural aspects are in (Calvo Capilla 2008). My research on the formal characteristics and the social, religious, and political meaning of the congregational and small mosques of al-Andalus were developed in my doctoral thesis (2001) published in (Calvo Capilla 2014a). 
Ibn Bashkūwāl (12th century), Ibn 'Idhārī (14th), and al-Maqqarī (17th) told a very eloquent and interesting anecdote that linked these two great architectural enterprises of the Andalusi caliphate. One of the first decisions made by al-Hakam II (961-76) as a caliph was to enlarge the dynastic congregational mosque of the capital. One day in the year 351/962, the caliph went to the Great Mosque accompanied by the Cordoban wise men, including the Māliki fuqah $\bar{a}^{\prime}$, the astronomers (ahl al-ta'dīl) of the court, the high judge ( $q \bar{a} \bar{d} \bar{\imath}$ Mundhir b. Sa'îd), and the șăhib al-ahbās of Cordoba. Al-Hakam II wanted their opinion regarding his plans to enlarge the building and the orientation of the qibla. On one hand, the astronomers of the court proposed to modify the qibla, to face east, following the correct orientation to Mecca, as had done his father, the Caliph al-Nāșir, in the Great Mosque of Madinnat al-Zahrā'. On the other hand, a prestigious jurist and theologian very close to the caliph, the faqīh Ishāa b. Ibrāhīm (d. after 963), known as Abū Ibrāhīm, opposed making any changes to the ancient qibla. The reason for this was that it represented the tradition and the precedent $\left(i t t i b \bar{a}^{\prime}\right)$ of the ancestors, and that modifying it would mean falling into a blameworthy innovation (ibtid $\bar{a}^{\prime}$ ) (Al-Maqqarī 1840, 1967).

This anecdote sparked a debate between science and the religious tradition with regard to the direction of the qibla wall that certainly revealed an interesting double ideological discourse, a dual way to legitimate the Caliphal dignity. When ensconced in the palace of Madinnat al-Zahrā', the caliph showed himself as an erudite ruler who promoted the rational sciences and the "knowledge of the Ancients", as recently pointed out in my study on the reuse of Roman sculptures in the Cordoban palace. At the same time, in the enlargement of the Great Mosque of Cordoba, the caliph appealed to the orthodox religious tradition to present himself before the umma as a ruler chosen by God and as the supreme Imam.

\section{The Legacy of the Umayyad Ancestors and the "Imperial" Aesthetics}

The second caliph, al-Hakam II, was, to a large extent, responsible for the conception of the cultural and artistic program of the new caliphate, i.e., for deciding the ideological message that works of art should convey about the new political context of al-Andalus, including urbanism, buildings, books, luxury objects, such as the fabrics of tiraz, ceramics, or ivories. The project to expand the capital's congregational mosque began with 'Abd al-Rahmān III, with the construction of a new minaret and the enlargement of the courtyard, and was completed by his son, al-Hakam II. The ornamental and architectural forms chosen in the new maqșūra of the Great Mosque, together with the epigraphic program, were clearly a visual expression of Umayyad legitimacy and its political aspirations, and the mosque became part of its $d a^{\prime} w a$ or politico-religious propaganda. Indeed, the enlargement became a political scenario, a sort of reception chamber, as we will see later.

The caliphal $d a^{\prime} w a$ included the claim of their rights over the eastern caliphate, and even as protectors of the Holy Cities of Mecca and Medina; it was part of the Umayyad ideology from the times of the Emirate of al-Andalus. Despite the utopian character of these pretensions, they appeared with some frequency in the official discourse of 'Abd al-Rahman III and al-Hakam II (Calvo Capilla 2008). As for their confrontation with the Fatimids, which was religious, because they were considered a heretical sect, and strategic, because of the hegemonic control of the Maghreb and the Mediterranean, the conflict was at its height in the middle of the 10th century, when the mosque was being enlarged.

A large part of the formal vocabulary of the caliphal mosque was thus inspired by religious models from the Umayyad past, both in the east and in Al-Andalus (Khoury 1996, pp. 86-88; Dodds 1992, pp. 18-23). The connection to their Umayyad ancestors could be seen in the use of literary topoi, in which al-Hakam II and the mosque of Cordoba were linked to al-Walīd (705-15) and the great mosque he built in the capital, Damascus (Calvo Capilla 2010b). (Figure 2) Since the enlargement was conceived as the architectural framework for the new power and its increasingly complicated ceremonial, it is logical that what Flood called the "imperial mosques" of the Umayyads-Jerusalem, Damascus, and Medina, built by 'Abd al-Mālik and al-Walīd between 685 and 715-were taken as the iconographic model (Flood 2001). Furthermore, there are certain features that could be considered 
a transfer of palatial architectural models to the prayer hall of the mosque, like the three central naves crowned by domes at their ends, clearly inspired by the basilical reception-halls of Madīnat al-Zahrā'.

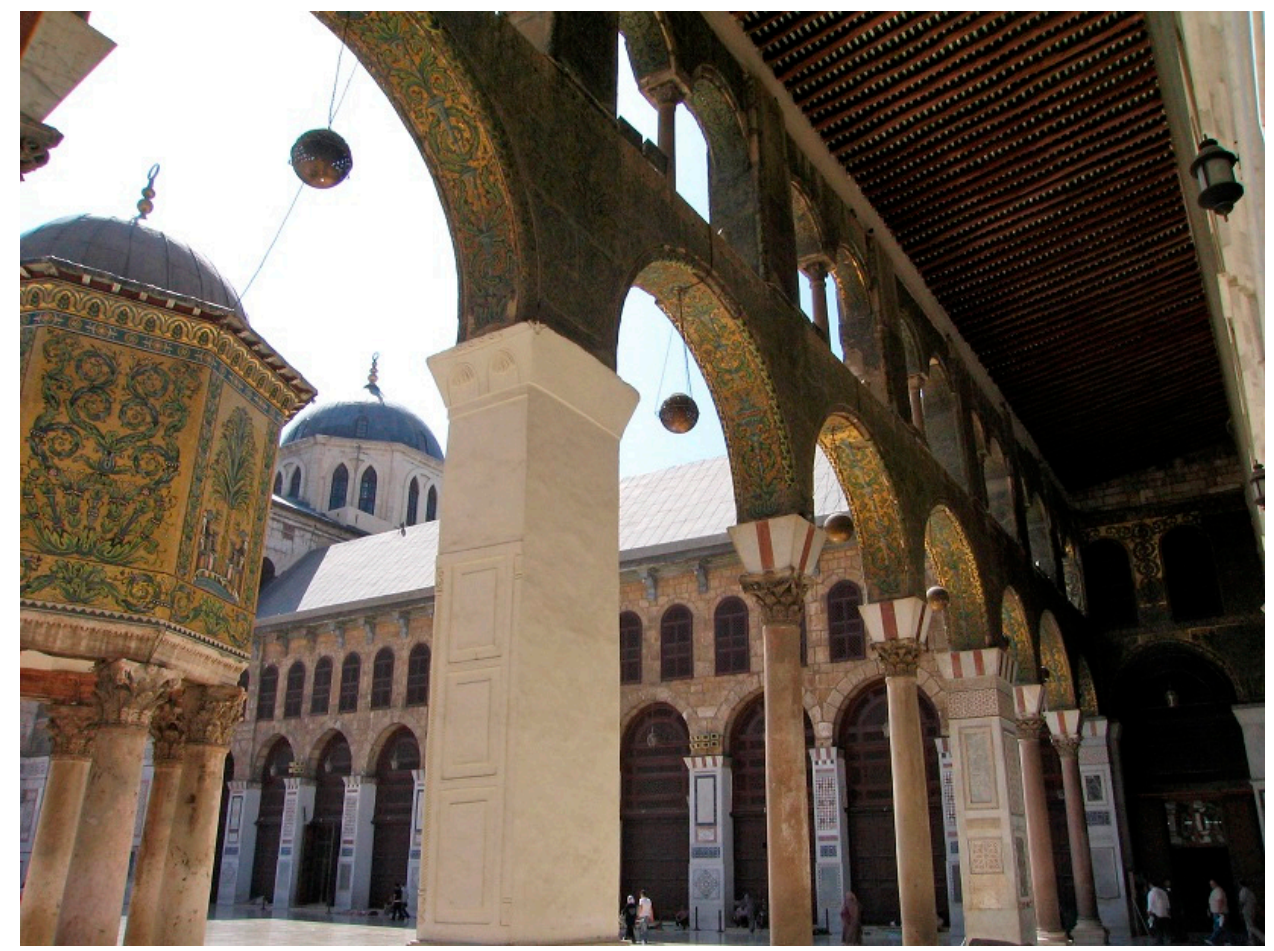

Figure 2. Umayyad mosque of Damascus (8th century). (C) Photo took by author.

Some other elements, such as the orientation of the qibla, the four columns at the entrance to the mihrab, and the scallop-shell vault over the niche, were connected to the Islamic past of al-Andalus. Thusly, the caliphs showed their attachment to the tradition of their ancestors, who in this case were the conquerors Musà b. Nusayr (712-14) and the $t \bar{a} b \bar{\imath}^{\prime} \bar{u} n$ who accompanied him, as well as the first Umayyad, 'Abd al-Raḥmān I "the Immigrant" (756-88), and 'Abd al-Raḥmān II. This was a means of sanctioning the rightfulness of the process of Islamisation of the Iberian Peninsula (Figure 3).

Paradoxically, in this process of self-assertion of the caliphate in the 10th century, the Umayyads of al-Andalus also took inspiration from the Abbasid caliphate, as the increasingly sophisticated ceremony and administration seem to indicate, as well as many aspects of protocol, from the honorary titles to the "imperial" aesthetics introduced in the caliphate's architecture. The tripartite structure of the qibla of Cordoba partly harks back to the arrangement of the wall in the two congregational mosques of Samarra, built by the caliph al-Mutawakkil (232-47/847-61). The mihrab is flanked by two bays, corresponding to the treasury chamber in the east and the sāba t door in the west ${ }^{2}$. This monumental triple façade in Cordoba (mihrab, treasury, and sābāt doors), decorated with glazed mosaics and preceded by domed bays, was an innovation that soon became the model, although simplified, for great mosques in western Islam. Similarly, the niche in Cordoba became exceptionally large $-3.77 \mathrm{~m}$ wide $\times 3.57 \mathrm{~m}$ deep, which is only comparable to those of the mihrabs in the two Abbasid mosques. Shortly after the mosaics of the sābat's door were finished (between 970 and 973), a new opening had to be made in the qibla wall to house the mobile minbar ordered by al-Hakam II (placed in the maqșūra in 366/976, as we will see below) (Figure 4).

2 (Northedge 2005; Leisten 2003; Creswell 1989, pp. 358-73). Golden mosaics were used in the decoration of the facade of the mihrab in the al-Mutawakkil mosque in Samarra (Herzfeld 1912, p. 10; Lamm 1927, pp. 106-10, 115-17). Sābāt is the passage that linked the mosque with the caliphal palace. 


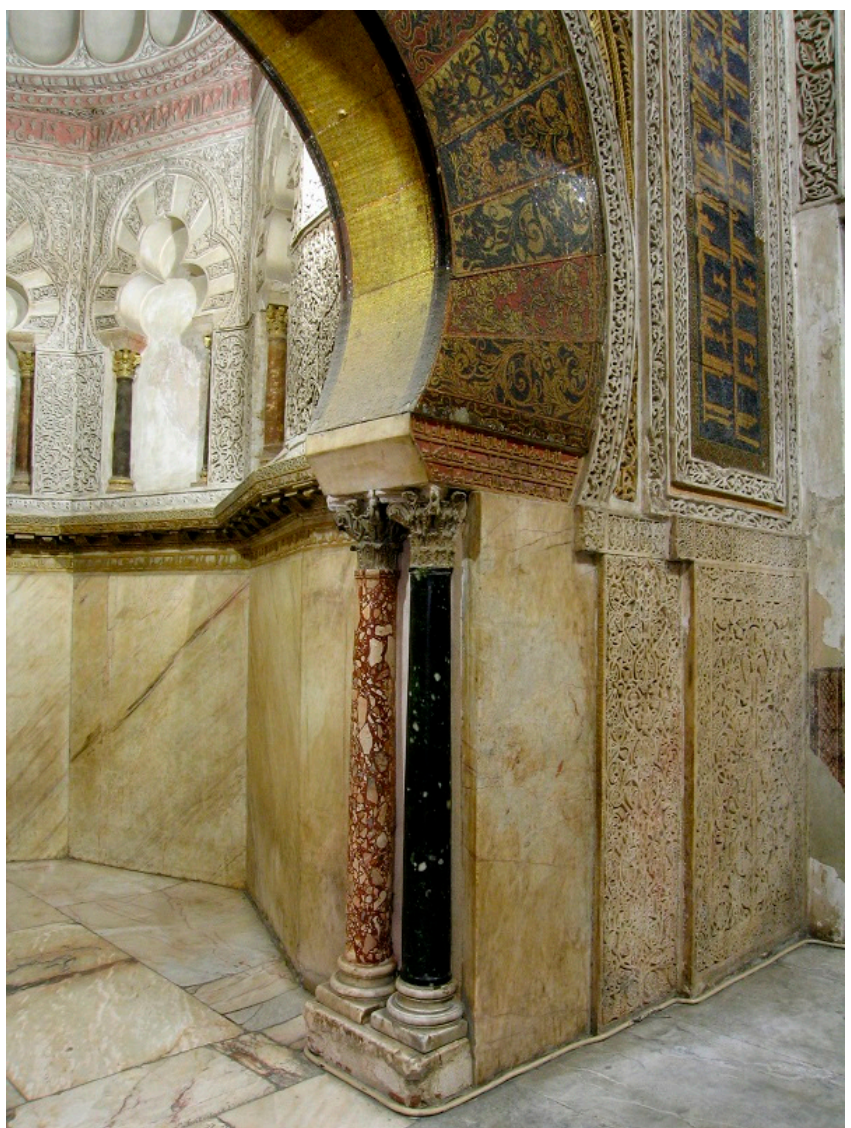

Figure 3. Mihrab of the caliphal phase of the Great Mosque of Cordoba with the columns of 'Abd al-Rahmān II. (C) Photo took by author.

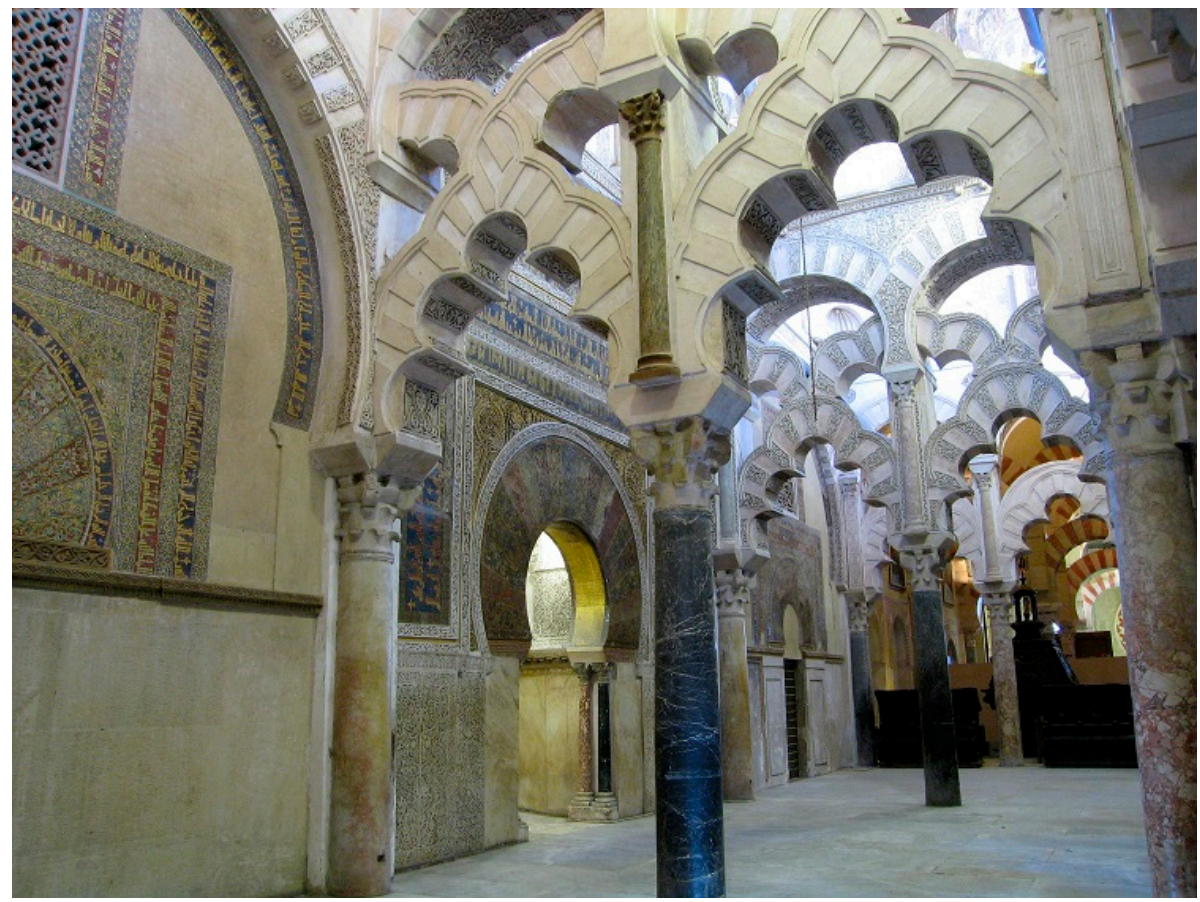

Figure 4. Great Mosque of Cordoba. Three domed triple bays of the maqșūra in the caliphal enlargement. (C) Photo took by author. 


\section{Domes and Chrysography for a Royal Scene}

Al-Hakam II's enlargement consisted of extending the eleven aisles to the south, underlining the importance of the three central ones with three ribbed domes at their northern end and three other ribbed domes at their southern end, crowning the bays of the maqșurra (Ruiz Souza 2001). The northern domes (with windows at their base) acted as a bright entrance to the caliphate's addition and the new maqșūra (Figure 5). All of these outstanding bays are bounded by screens of intersecting polylobed and horseshoe stone arches. Once the expansion works began, the initial project was re-designed with the introduction of an arcade that runs parallel to the qibla wall, extended on both sides of the aforesaid screens. There is no "qibla nave" strictly speaking, but this arcade marks out a privileged area next to the qibla (Momplet Míguez 2012, pp. 240-41).

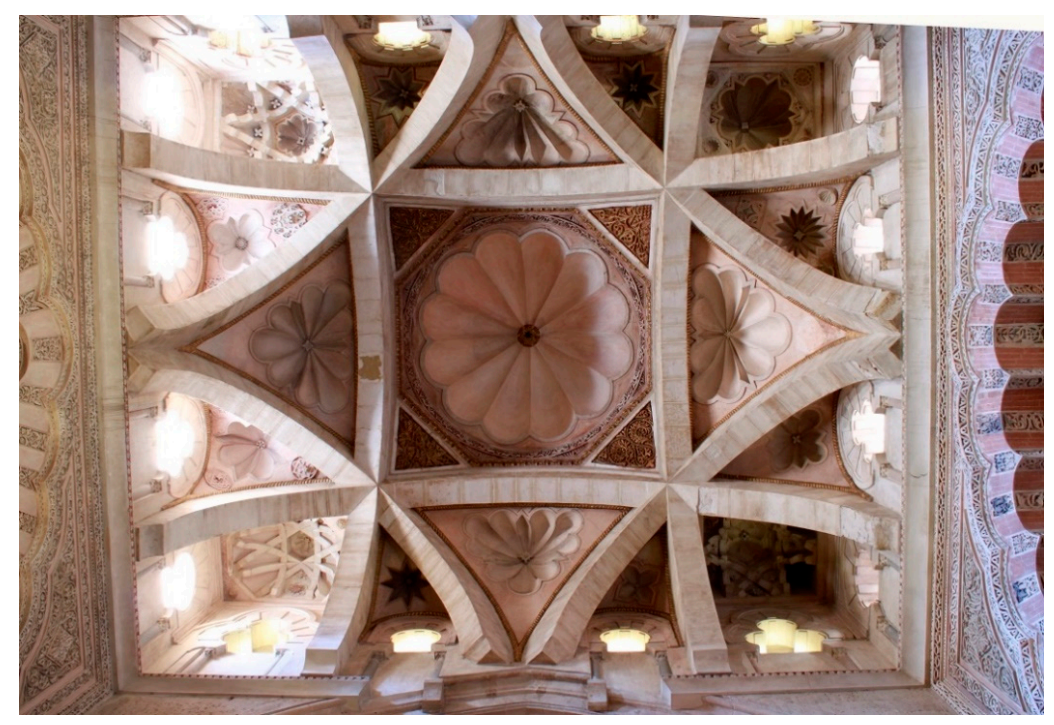

Figure 5. Great Mosque of Cordoba. Ribbed dome at the northern end of the axial nave in the caliphal enlargement (10th century). (C) Photo took by author.

As the faithful move southward along the new axial nave, wider than its two adjacent naves, the spatial perception changes. From the northern end of the axial nave (now called Villaviciosa chapel), the maqșūra and the mihrab façade, also illuminated by the openings at the base of the dome, seem to be closer, as if the central nave does not exist (Figure 6). The three-dimensional space re-emerges after crossing the screen of intersecting arches. In this axial nave, imaginary diagonal lines converge, traced by the colour of the marble shafts of the columns (rose-coloured and dark-blue) that lead to the mihrab, as described by Ewert's studies (Ewert 1995). Likewise, at the front of the arcades of the axial nave, there are pilasters carved with ornamental elements and a double epigraphic frieze surrounds the nave under the roof. All these elements mark the path to the qibla, the symbolic way to salvation. On the facade of the mihrab, the arrangement of the marble slabs in the arch jambs emphasizes the perspective and the depth of the niche, which looks like a door to paradise, as Grabar pointed out (Grabar 1988), or the place of the divine light, as argued below.

The concept of a monumental maqșūra in three bays is somewhat unusual, but not the vaults chosen for each of them: the domes (Figure 7). The dome (qubba) has been the space representing supreme power since ancient times and could already be found in the congregational mosques from the Umayyad era. The political and religious symbolism of qubba-s in Islam, as well as their colour and decoration, is well-documented in the Middle East ${ }^{3}$. Some traditions (hadith-s) place 
the meeting between God and Muhammad in Jerusalem during his isra $\bar{a}^{\prime}$ or night journey under a red tent (Van Ess 1992, pp. 96, 102; Bloom 1993, pp. 135-41). During his military campaigns, Caliph $\mathrm{Mu}$ 'āwiya took with him a qubba adorned with "precious stones" to house the Quran. In that same tent, he received the oath of allegiance (bay'a) from the troops (Lammens 1920, pp. 46-68).

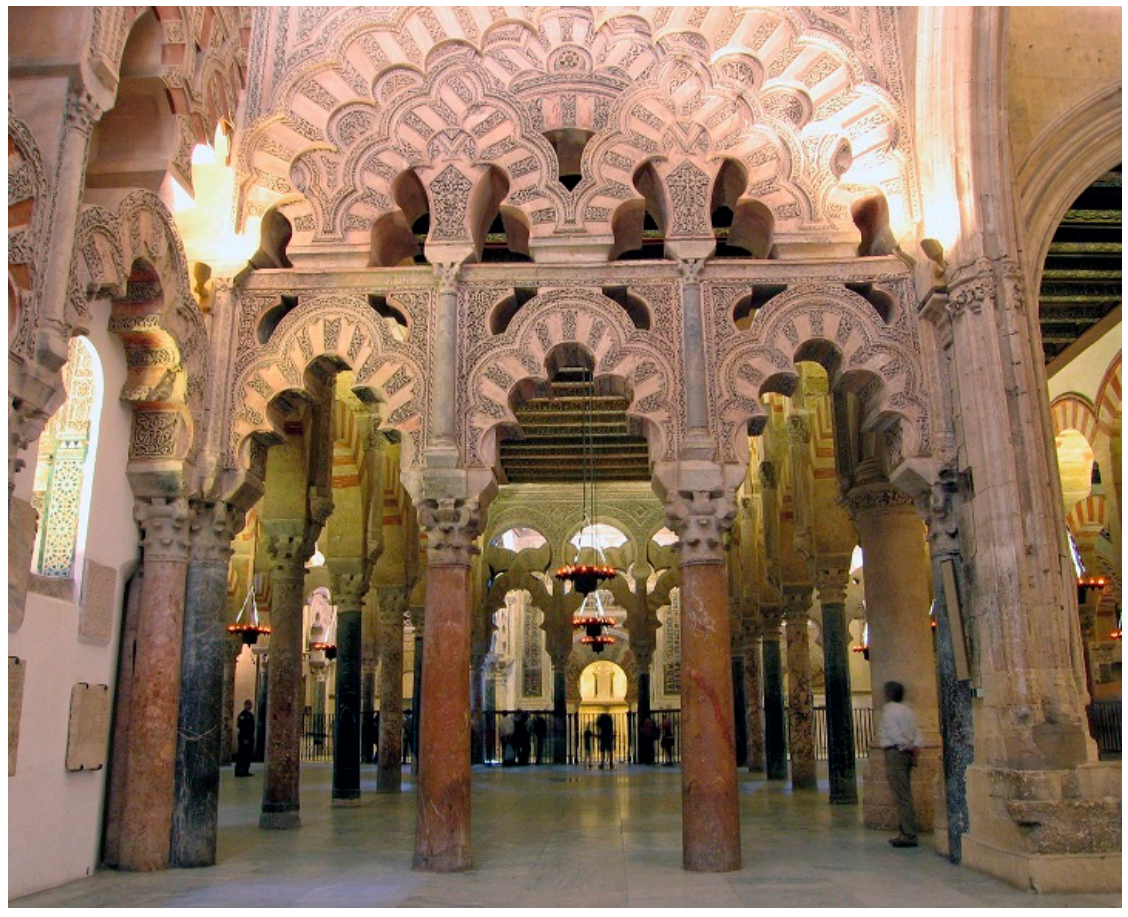

Figure 6. Great Mosque of Cordoba. Northern end of the axial nave of the caliphal enlargement (now called Villaviciosa chapel). (C) Photo took by author.

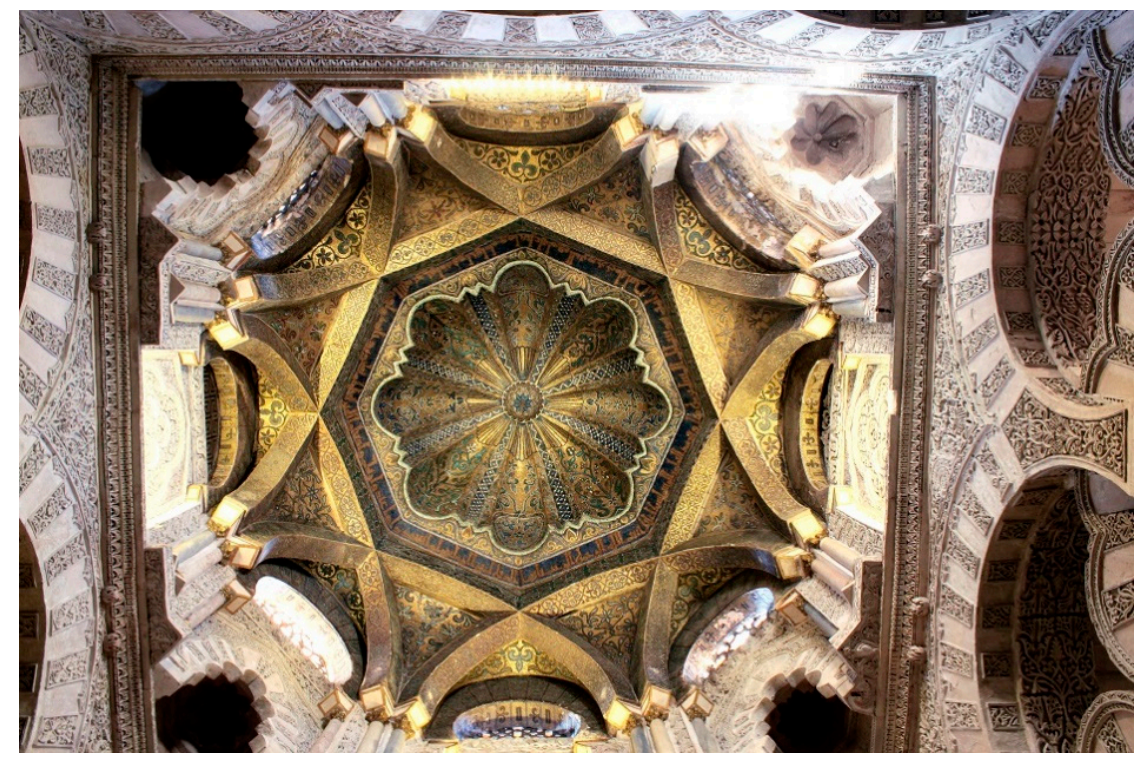

Figure 7. Great Mosque of Cordoba. Ribbed domed bay in front of the mihrab. ( Photo took by author.

Mosaics, colour, and light contribute decisively to emphasising the area of the maqșūra, which was the scenario where the sovereign displayed himself. Light is a divine attribute; it is the symbol of intellect and justice against chaos and darkness (Calvo Capilla 2008, pp. 94-95; Puerta Vílchez 2007, 
pp. 62-64, 144-50). Colour and word, according to the thinker Ibn Hazm (384-465/994-1064), are the light providing access to the world, to ideas, to revelation and, of course, to beauty in all its facets: physical, ethical, and spiritual ${ }^{4}$. Luminosity and a harmonious combination of colours create beauty according to Islamic aesthetics. Precious stones or gold combine these two facets and are essential components of this symbolism. Along the same lines, the recent studies by Alain George (2009) highlight the use of colours and gold in the monumental epigraphy of the Umayyads and Abbasids and in the chrysography of the early Qurans. The brightness of the gilded letters and precious stones against a dark blue or red background has both a royal or imperial connotation and a sacred meaning: the divine light in the darkness, light as a guide $(h u d \bar{a})$, a rather frequent tenet in the Quran (Figure 8).

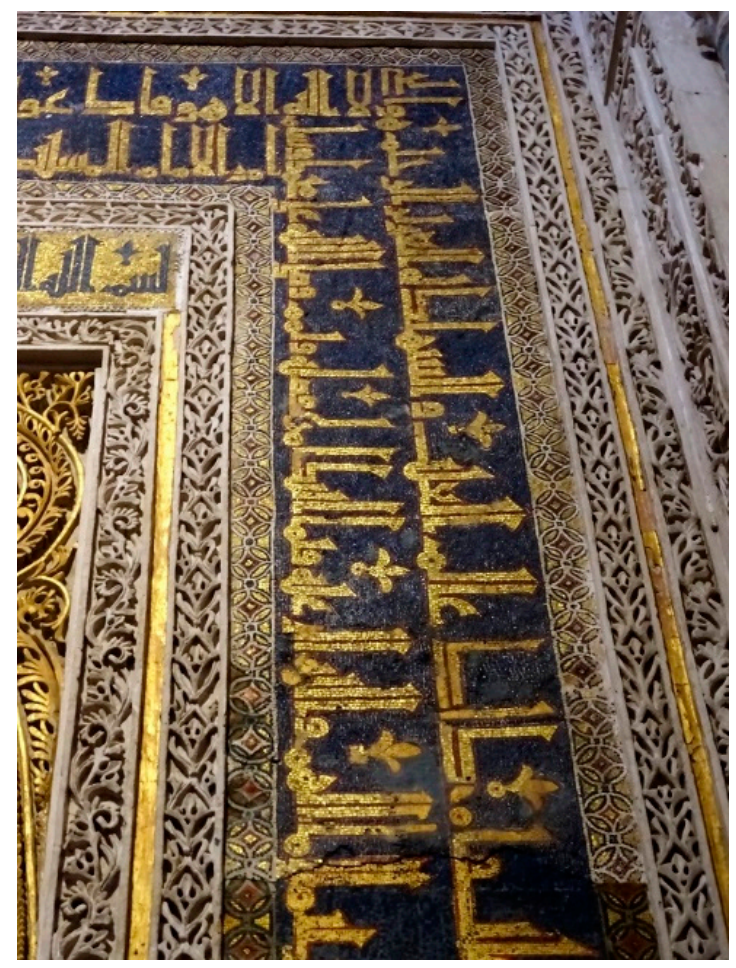

Figure 8. Great Mosque of Cordoba. Detail of the mosaic decoration on the mihrab façade. (C) Photo took by author.

Common in mediaeval Islamic and also Byzantine aesthetics was the mineralization of living nature and architecture, in order to provide them with transcendental qualities. In this sense, buildings and gardens are transformed through visual metaphors into precious jewels, thus acquiring the character of perfect, infinite, and eternal beings, in manifestations of divine light and the power emanated from God on Earth (Cutler et al. 1996, pp. 185-90).

Similar to the Dome of the Rock, the central dome of the maqșüra in Cordoba was a kind of architectural baldaquin housing the intangible throne of God, a jewelled tent with astral symbols situated between heaven and earth. This space became the emblem not only for a divine presence, but also for the absolute, earthly, and spiritual power of the caliph of Cordoba, derived from the heavenly throne (Figure 7).

The scallop-shell forms, used in the maqșura not only as ornamental decorative motifs but also in the vault of the caliphal mihrab, should also be interpreted as a metaphor of the divine light, as Arab

4 (Puerta and Miguel 1997, pp. 492-503). Also in English: 2017. Aesthetics in Arabic Thought: From Pre-Islamic Arabia Through al-Andalus. Leiden. Furthermore, (Puerta and Miguel 2013). 
authors stated (Calvo Capilla 2010b, pp. 298-99). This motif, present in the Umayyad mosques of Medina and Damascus and in the first mosque of Cordoba ${ }^{5}$, as said, also reveals the desire of the Umayyads of Cordoba to display their links with their eastern ancestors (Figure 9).

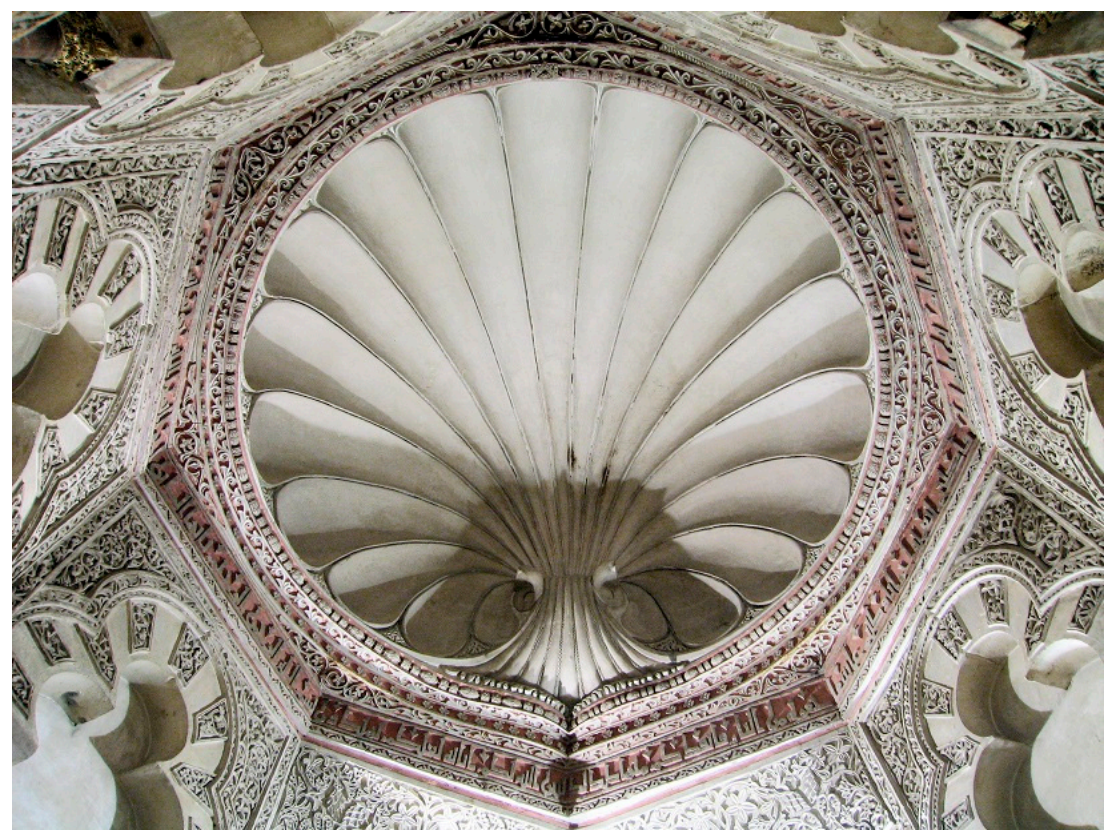

Figure 9. Great Mosque of Cordoba. Scallop-shell vault of the caliphal mihrab (10th century). (C) Photo took by author.

Two other objects linked the Great Mosque of Cordoba with the time of the Prophet and the "Well Guided" caliphs: the Muṣhaf, supposedly once owned by Caliph 'Uthman and kept in the mosque, and the above-mentioned mobile minbar. These two objects were treated as relics (al-āthār al-sharīfa) and shown in the maqșüra during the Friday congregational prayer.

The origin of this manuscript of the Quran, which belonged to the Umayyads of al-Andalus, has not yet been determined, despite recent interesting studies. Several articles have analysed Arab sources that mention its ceremonial use by the Almohad caliphs. The work of Zadeh (Zadeh 2008; Dessus-Lamare 1938) seems to confirm that the Quran was not an "inventio" of the Almohads but, on the contrary, that it already played an important role in Cordoba in the 9th and 10th centuries, although the ceremonial described by al-Idrīsi was probably from the 12th century. The older authors pointed out that the Muṣhaf kept at the Great Mosque of Cordoba, whatever its origin, 'Uthmānī or not, served as a sacred object, a kind of relic in the liturgical setting, and also as a propitiatory object (Calvo Capilla 2018b).

As for the new minbar or mobile pulpit, it was installed in the caliphal maqșūra most likely before jumādà II 365/February 976, the date of the celebration of the bay'a or oath of allegiance of the heir Hishām II (eight months before the death of al-Hakam II) (Hernández Giménez 1959, p. 381; García Sanjuán 2008). The minbar had nine steps and was made of precious wood. It moved on four wheels and was kept in a room behind the qibla. According to different studies, the mobile chair model was probably chosen to create a link with the mosque of the Prophet in Medina, which was needed to legitimize the bay'a ceremony of the prince Hishām, who was then a minor (Fierro 2007; Bloom et al. 1998).

5 The remains of the first mihrab had been analyzed by (Fernández Puertas 2015, pp. 299-305, 326-28). 


\section{Politico-Religious Apologia through the Quranic Inscriptions}

From recent studies by Bierman (1989), Blair and Bloom (2006), Grabar (2006, pp. 59-63) , Montasser (2009), or Tabbaa (1991; 2001, pp. 53-72), among others, there can be no doubt that the Quranic inscriptions often transmit an ideological discourse, an "iconographic message", according to Grabar $(1988,1996)$. The foundational inscriptions, in which patronage, historical data, and political messages are more evident, serve to complete the information. The epigraph program can be more easily identified in buildings preserving a representative set of inscriptions from the Quran. The epigraphs can be single quotes from the Quran or complex texts, compositions or combinations of verses ( $\bar{a} y \bar{a} t)$ (complete verses, partial excerpts, paraphrases, consecutive or non-consecutive verses of the same sura or chapter, interspersed verses from different suras). It is rather uncommon and atypical for the epigraphic text to be composed of fragments of verses, diverse chains of $\mathrm{Qu}^{\prime}$ ranic sections, or unusual suras. In the case of the earliest religious monuments, we are lucky to have a set of original epigraphs preserved almost completely intact in the Dome of the Rock, in the Mosques of Ibn Ṭūlūn and al-Hākim (both in Cairo), and in the Great Mosque of Cordoba (Grabar 2006; Swelim 2015; Bloom 1983). In later ages, we can also find complete programs in certain Ayyubid and Mamluk monuments (Tabbaa 2001; Montasser 2009).

In the caliphal enlargement of the Great Mosque of Cordoba, the epigraphic program contains a selection of Quranic verses consciously chosen by the ideologists of al-Hakam II to expose the Umayyad da'wa. A "new" text was composed with Quranic excerpts and partial quotations to express a specific message more accurately and effectively. This was achieved by resorting to rhetorical means similar to those used in edicts, official speeches, or texts, as well as in the khutbas, in which quotes from fragments of the Quran were commonly used to emphasise or reinforce an idea or argument and to express it more eloquently. One of the first scholars to bring attention to the iconographic content of the program was Nuha Khoury (1996), who interpreted the messages as a generic claim of the Umayyads over tradition and the caliphate, thus strengthening the divine nature of their mandate: "The epigraphic program of the Cordoba mosque combines with its mythical and historical dimensions to project the monument yet another step back in time, making it a counterpart of the mosque-shrine founded by the Prophet." Thereby, according to the same author, they presented the dynastic mosque as an universal Islamic shrine, like Mecca and Medina. However, it seems to me that the Cordoba mosque is not modelled on the Medina one, but rather on Damascus Umayyad mosque, and actually, I believe that many Andalusi references were introduced into the politico-religious discourse displayed in the Great Mosque of Cordoba.

Before continuing with an analysis of the epigraphs, it is important to explain where they have been preserved (Figure 10). On the exterior part of the building, inscriptions are located on the doors of the two 10th century enlargements, one by al-Hakam II and the other by his son, the caliph Hishām II in the 980s (although the works were directed by his hājib al-Mansūr). They are partially preserved on the western façades and are more intact on the eastern façades. Inside, they can be mostly seen in the qibla and maqșüra area, as well as in the central nave. The most well-preserved are the ones carved in marble; many others, carved in wood or painted, have mostly disappeared (Figure 11).

Together with the universal religious messages, which are liturgical and dogmatic in the interior, while eschatological and for indoctrination on the doors, the most remarkable aspect of the epigraphic program in the Great Mosque of Cordoba is a specific set of messages that are apologetic and controversial in nature, and that gave an ideological response to several transcendent concerns of the caliphal power in the 10th century.

Some of the inscriptions were used to theologically refute the heterodox or directly heretical currents spreading in al-Andalus, which were viewed as dangerous political dissent. The inscriptions displayed the basics of orthodox doctrine that ensured consensus among Muslims, with regard to 
an order presided over by divine will. In al-Andalus, this orthodoxy was defended by the prevailing school of jurisprudence, the Māliki, publicly supported by the caliph. Consequently, fuqah $\bar{a}^{\prime}$ backed the ruler's divine power (Marín 2011, pp. 286-87).

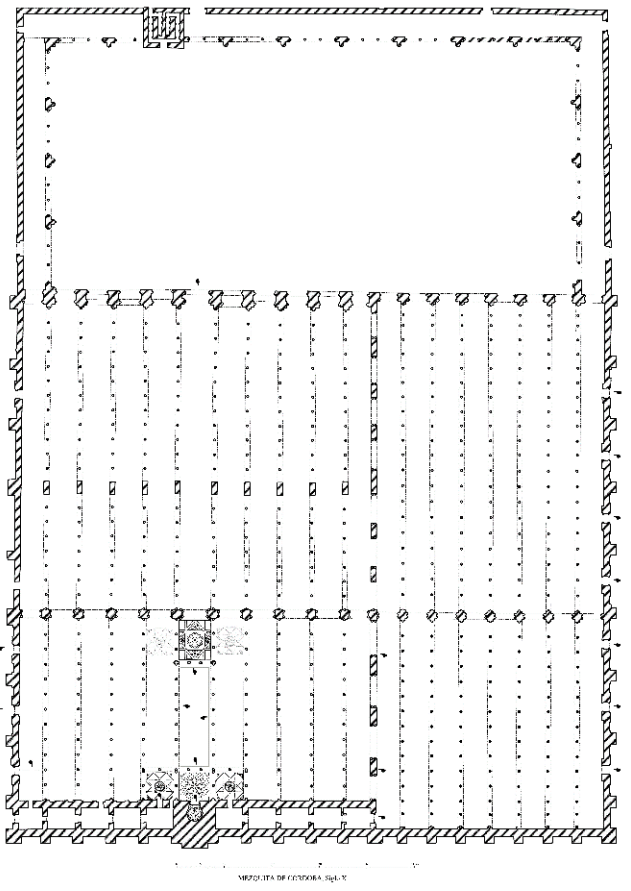

Figure 10. Plan of the Great Mosque of Cordoba. The signs indicate the location of the inscriptions. Based on the plan of A. Almagro (Calvo Capilla 2014a).

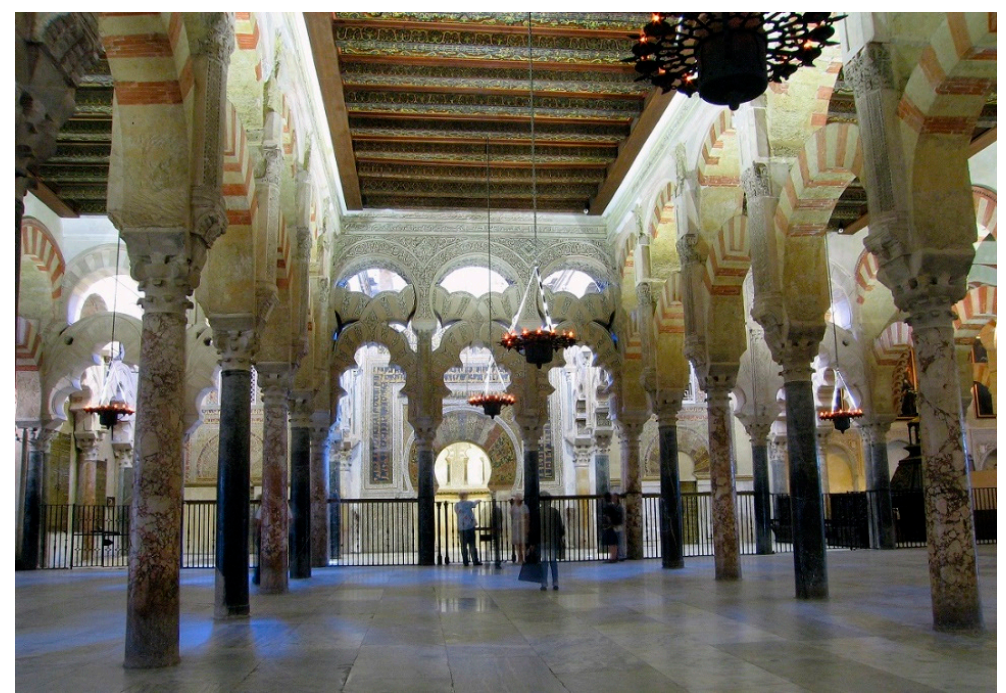

Figure 11. Great Mosque of Cordoba. Panoramic view of the axial nave to the qibla wall. (C) Photo took by author.

Among these "heterodox" currents, one of the most important and concerning for the caliph was the one created by Ibn Massarra (269-319/883-931) and his followers. Although today he is known as the first scholar to spread mysticism in al-Andalus, some of his dogmatic positions were considered heretical by fuqahă' (jurists) and Māliki theologians in the 10th century. After the death of Ibn Masarra, his disciples continued growing in number and their positions became more extreme. Thus, between 
952 and 957 a statement condemning masarrism was read three times before the gates of the great mosques of al-Andalus, and in 961 his books were burned in front of the Great Mosque of Cordoba.

The most dangerous aspect of their thinking was the apologia for the doctrine of free will. This idea, which stemmed from the Mu'tazilī school in the East, had been rejected and even persecuted by the Umayyad Caliphs of Damascus, the Abbasids and the Fatimids. The reason was that free will represented a threat to the established order and the very foundations of caliphal power, because it defied the principle of authority. Religious determinism, instead, represented a fundamental pillar of the absolute power and infallibility of the caliph, ensuring subservience and obedience from the Umma (community of Muslims). These principles are clearly stated in the official propaganda texts of the Caliphate of Cordoba.

Masarrism also believed in the createdness of the Book, in opposition to the Sunni creed. With this notion, they adopted the same position in the debate over the nature of the Quran as the Umayyads enemies, the Fatimids. As recently studied by Johns (2018) in the Quran presumably copied in Palermo in 372/982-3, this theological view was one of the major points of dissension between Sunni and Fatimids in the North of Africa. Indeed, verses that reinforce the idea of predestination and the divine revelation of the Quran are significantly present in the Cordovan enlargement program (in the central nave, the maqșūra, and the doors).

This topic leads us to a second important threatening current at that time: the spread of the Shi'i propaganda. The caliphal authorities suspected that secret agents of the Fatimid state were propagating their creed, considered "heretical" by the Sunni caliphate, throughout al-Andalus 7 . Masarrism, as much as Shi'a religious ideas, led to social and religious instability and broke the doctrinal unity of the umma wāhida or a 'single community'.

Christians were a third concern. In 928, 'Abd al-Rahmān III put an end to the rebellion of 'Umar b. Hafsūn, who was accused, apart from insurrection, of apostasy (he converted to Christianity) and of being a Fatimid agent. The Christian community (dhimmis) in Cordoba was large, and there had been cases of apostasy even within the Umayyad family in the early 10th century. Christians were also the foreign enemy (al-käfirūn or unbelievers). It cannot be by accident that Quranic verses denying the divine nature of Christ appear on three doors, one inside and two outside, all located near the qibla wall; there, we found three different verses with the same meaning, a refutation of the two doctrines of the Trinity and divinity of Christ. The association of the three quotations and their location, as well as the complementarity of the external and internal verses, confirms that they were put there purposely (Figure 12).

These three threats were undoubtedly present when conceiving the politico-religious message inscribed on the caliphal mosque walls. Apologetic texts seem intended to provide Muslims with arguments for believing in the destiny marked out by God and to secure their faith by distancing themselves from heresies and the Christian creed.

The message was reinforced on the mosque western doors opposite the Alcázar (royal palace) with inscriptions urging the faithful to be pious and follow the straight path by reminding them of the severity of God's supreme justice and, implicitly, the earthly justice delivered by his representative on Earth, the caliph. The Quranic texts would be a reminder to the faithful that they were subject to both divine and earthly justice. If they are tested, they revert to their old ways, losing both this world and the next-that is the clearest loss (Q. 22:11), said Qāḍ̂̄ Mundhir b. Sa'īd (m. 355/965-66) in one of his sermons. Official edicts, proclamations and sentences were read out before the doors of the Great Mosque of Cordoba, a sign of their importance as socio-political showcase.

Other common messages, of a missionary and eschatological character, are also found on the doors. Inscriptions often close with the Tasliya, praise to the Prophet, which was recited on entering

7 Another singular aspect of the Mosque of Cordoba is that there is no known intervention of damnatio memoriae or modification of a previous inscription in the Islamic period. Maybe they existed, but those have been lost. (Abdeljaouad 2018; Bloom 2015). 
and leaving the mosques (De la Puente 1999, pp. 121-29). The texts urged them to give alms (on the east and west doors) and also reminded Muslims of the dangers at the time of death and the Day of Reckoning, which explains why calls to attend funerals and pray over the dead on their stretchers were made from the doors (Figure 13).

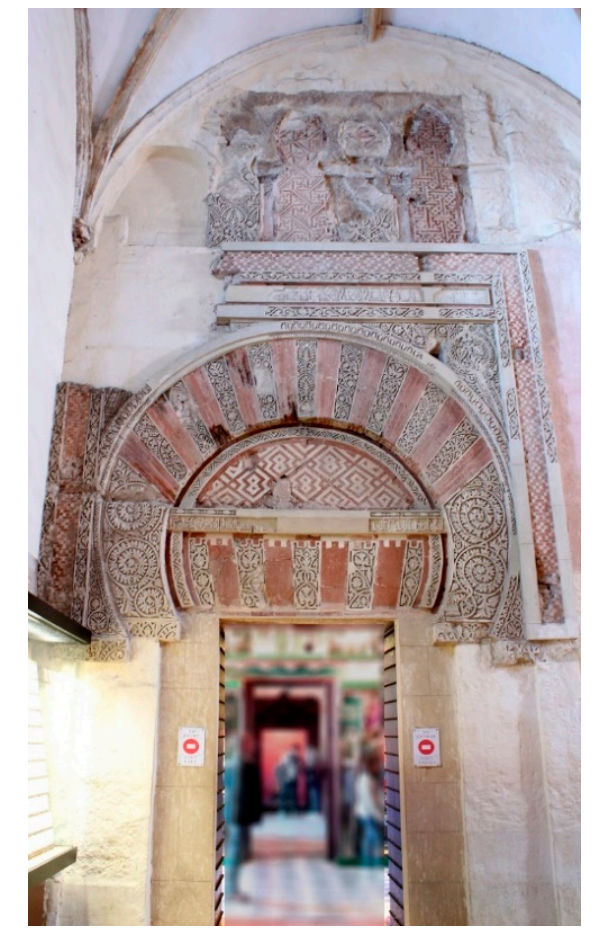

Figure 12. Great Mosque of Cordoba. Eastern door of the al-Hakam II's enlargement, called "del Punto" and located next to the qibla wall. (C) Photo took by author.

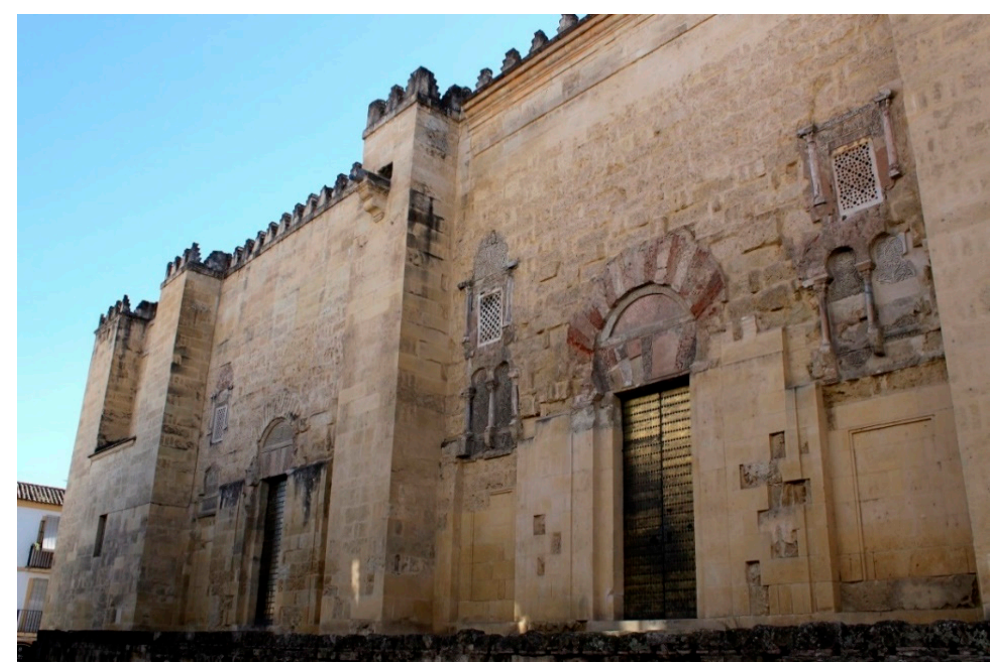

Figure 13. Great Mosque of Cordoba. Southeastern doors of the Hisham II's enlargement. (C) Photo took by author.

They all supported the Andalusi Umayyads' claim to legitimacy in proclaiming the caliphate and their ambitions towards the Middle East, praising al-Hakam II as the supreme imam, 'amīr al-Mu'minīn or "emir of the believers", pillar of the truth (al-haqq) and of Islam, and the true heir of the Rashīdurn caliphs (Rightly Guided) and of the eastern Umayyads (lbn and Halaf 1965, pp. 177-78; 1967, pp. 217-19). 


\section{On the Forms of Epigraphic Settings}

In the inscriptions of the al-Hakam II's enlargement, the floriated Kufic, used in his father's time, was replaced by simple Kufic. As some specialists have pointed out, attention should be drawn to the fact that floral finials were suppressed in the calligraphy of the great mosque. We can only find simple motifs, like the half-palmette at the end of the letter nūn, as well as the fleur-de-lis and other flowers with four petals placed above the words, without interfering with the letters ${ }^{8}$. Clearly, the use of simple Kufic facilitated reading and intelligibility.

I recently had the opportunity to study the epigraphic bands of the central nave of the caliphal enlargement. This nave contains two inscriptions in relief that are carved in two parallel stone friezes below the wooden roof. The epigraphic friezes under the roof in the other naves were likely made of wood, as mentioned by al-Idrīsī (d. 1164) and al-Maqqarī (d. 1632): "under each roof [sam $\bar{a}^{\prime}$, literally "sky"] there is a wooden frieze (izär) where verses of the Quran are written." (Al-Idrīsī 1949, pp. 6-7) One small fragment of that frieze survives, preserved in the Archaeological Museum of Cordoba ${ }^{9}$. Al-Maqqarī said that the inscriptions chosen for each location were intended to "stimulate the minds of the faithful to contemplation and devotion." (Brisch 1959, p. 185; Al-Maqqarī 1840, v. I, cap. 3, pp. 231, 501; 1967, vol. 1, p. 369).

Rodrigo Amador de los Ríos read the inscriptions visible before the restorations of this central nave (Figure 11). Only a few errors in identifying the verses are detected in his reading. The double inscription begins at the far right of the screen of intersecting arches delimiting the maqșüra (Figure 14) and continues in the east arcade; two separated inscriptions decorate the screen of intersecting arches (delimiting the Villaviciosa chapel, at the north end of the nave) ${ }^{10}$, and, finally, two other parallel friezes decorate the upper part of the west arcade ${ }^{11}$. Obviously, the epigraphs run from right to left. Only the sura 3 is inscribed on all four sides of the nave, on the lower frieze, although its verses are not copied in order.

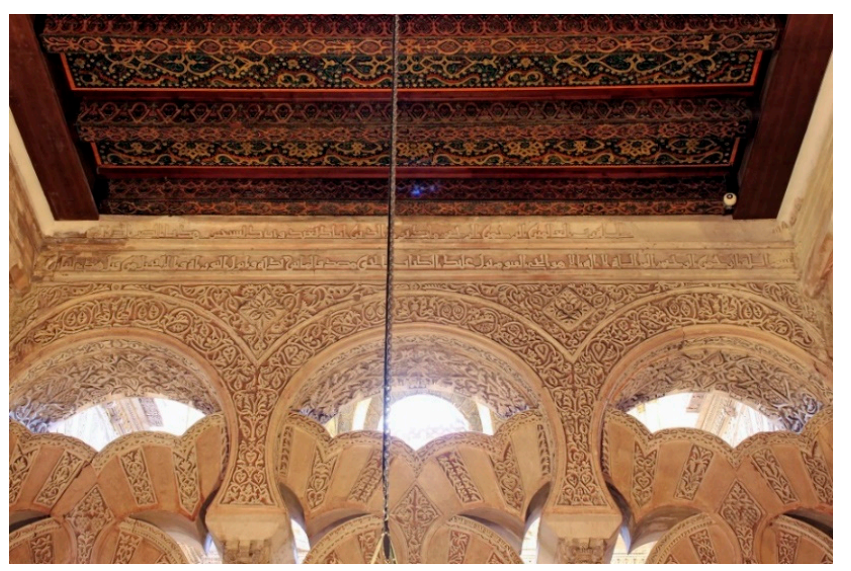

Figure 14. Great Mosque of Cordoba. Screen of intersecting arches delimiting the central bay of the maqșūra. (C) Photo took by author.

8 According to Martínez Núñez (2015, pp. 37-38), the definitive consolidation of the simple kufic occurred in the inscriptions of the extension ordered by al-Hakam II in the Mosque of Córdoba. For the evolution of the kufic script, see Ocaña Jiménez $(1970,1988)$.

9 Hernández Giménez (1928, pp. 197, 207-8); Cabañero Subiza and Ontañón (2001, pp. 273-74, Figure 7). Only one fragment of the epigraphic frieze is known so far.

10 In the upper frieze on the intersecting arches delimiting the Villaviciosa chapel are Q. 3:18 (complete), that is, the Tahli $l$, a variant of the profession of faith, plus the first sentence of 3:19. Basmala plus Q. 33: 70-71 are in the lower inscription. All the details are analysed in a forthcoming article.

11 On the west side, the lower frieze contains fragments of Q. 3:190-94; in the upper frieze, we found a small fragment of Q. 20:110, probably preceded by 20:109 and followed by 20:111; the remaining half of the upper frieze is occupied by Q. 2:286, which was probably partially cited (as in the sābāt façade). 
An interesting decorative detail draws attention. In the epigraphic bands on the east side, three decorative elements have been preserved; unlike those in the mosaic inscriptions, they are separating words; specifically, they are placed separating two non-consecutive verses from the same sura (Q.3 and Q. 2) $)^{12}$. The fragmentary state of the inscription prevents us from knowing whether there were more markers in the west arcade and if they always separated non-consecutive verses or even verses from different suras. Nor have we located other examples preserved in the mosque, but that does not mean they did not exist (Figure 15).

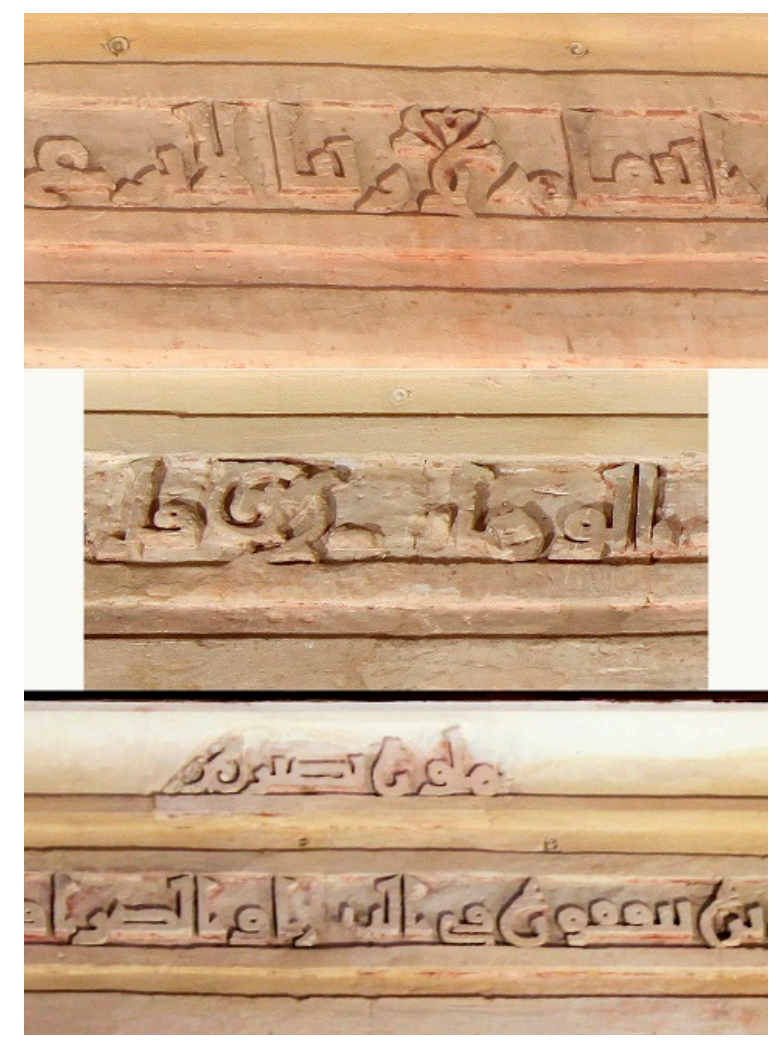

Figure 15. Great Mosque of Cordoba. Details of the Kufic inscription at the top of the wall in the axial nave. (C) Photos took by author.

The best known parallel that comes to mind is, again, the Dome of the Rock, whose inscriptions have recently been analysed by Milwright (2015). On the outer side of the octagon-ambulatory, circular motifs framed in squares are used to separate not verses but sections of the text (composed by basmala plus Quranic periphrasis plus tașliya). Although they have been related to the illuminated markers between verses in the Quran manuscripts, they do not have the same function in either case, in either Jerusalem or Cordoba. In the case of the Cordoba, motifs do not derive from the abyad annotation or from the Quranic markers (rosettes and dots): the three preserved examples are a stylised double stem, a double palmette, and a scroll. They are, rather, similar to the floral motifs inserted in the coins minted by al-Hakam II between 352 and 357H/963 and $968^{13}$ (Figure 16).

12 On the east side arcade run also two inscriptions. The lower one contains probably full verses of Q. 3, not consecutive and separated by a decorative motif: Q. 3:4 $80+3: 880+3: 26$ [i 80 ? ] 3:133-34. The upper one contains a fragment of the $Q$. $2: 11080$ (separating mark at the end of this verse).

13 The dates of the coins coincide with those of the construction of the mosque. See similar motifs in the dirhams of al-Hakam II preserved in the Museo Arqueológico Nacional (MAN): $\mathrm{n}^{\circ}$ inv. 2008/103/85 (352H/963-4), $\mathrm{n}^{\circ}$ inv. 2008/103/129 $(353 \mathrm{H} / 964-5), \mathrm{n}^{\circ}$ inv. 2008/103/213 (354H/965) or $\mathrm{n}^{\circ}$ inv. 2008/103/211 (354H/965), $\mathrm{n}^{\circ}$ inv. $104314(357 \mathrm{H} / 967-8)$. Also, in http:/ / www.andalustonegawa.50g.com/alHakamII.htm (Coins of al-Andalus in the Tonegawa collection). 


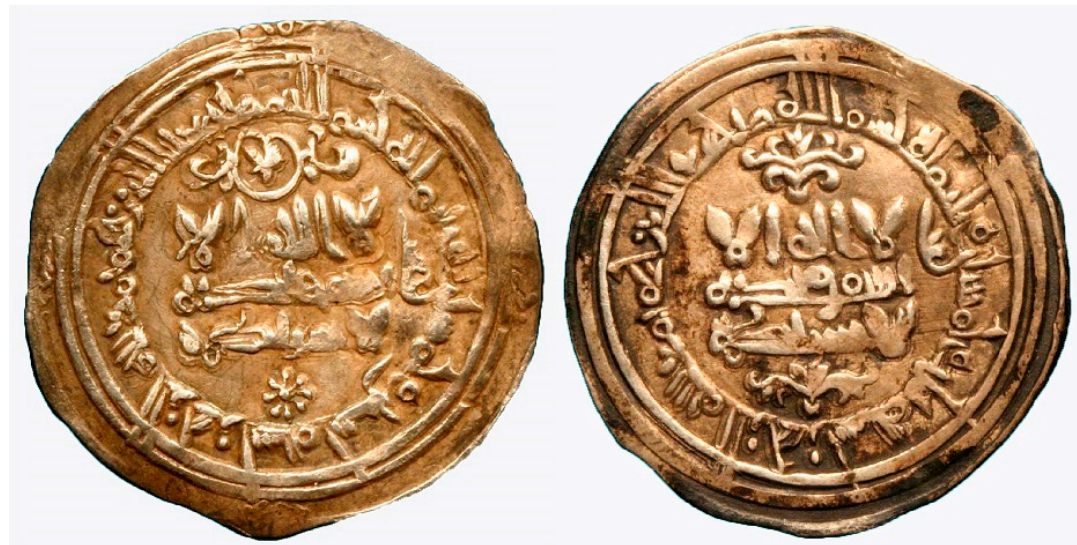

Figure 16. Dirhams of al-Hakam II: 963-964/352H (MANF2008_103_85_P) and 964-965/353 H (MANF2008_103_129_P) coined at the mint of Madinat al-Zahra'. Museo Arqueológico Nacional, Madrid. Photo: María del Mar Gómez Talavera, (C) In public domain.

Legibility was also improved by location and colour. It is worth noting that, on some of the external doors, the carved words stood out against a background of lapis lazuli blue and were framed by red bands (Figure 17). In the inner epigraphic stone friezes (maybe also the wooden ones ${ }^{14}$ ) located under the roof, some remains of red still exist in the background. The letters were probably painted too, perhaps gilded as in the mosaics of the maqșura. Finally, some of the inscriptions were not in relief but painted red, as in the arch located in the west end of the arcade parallel to the qibla.

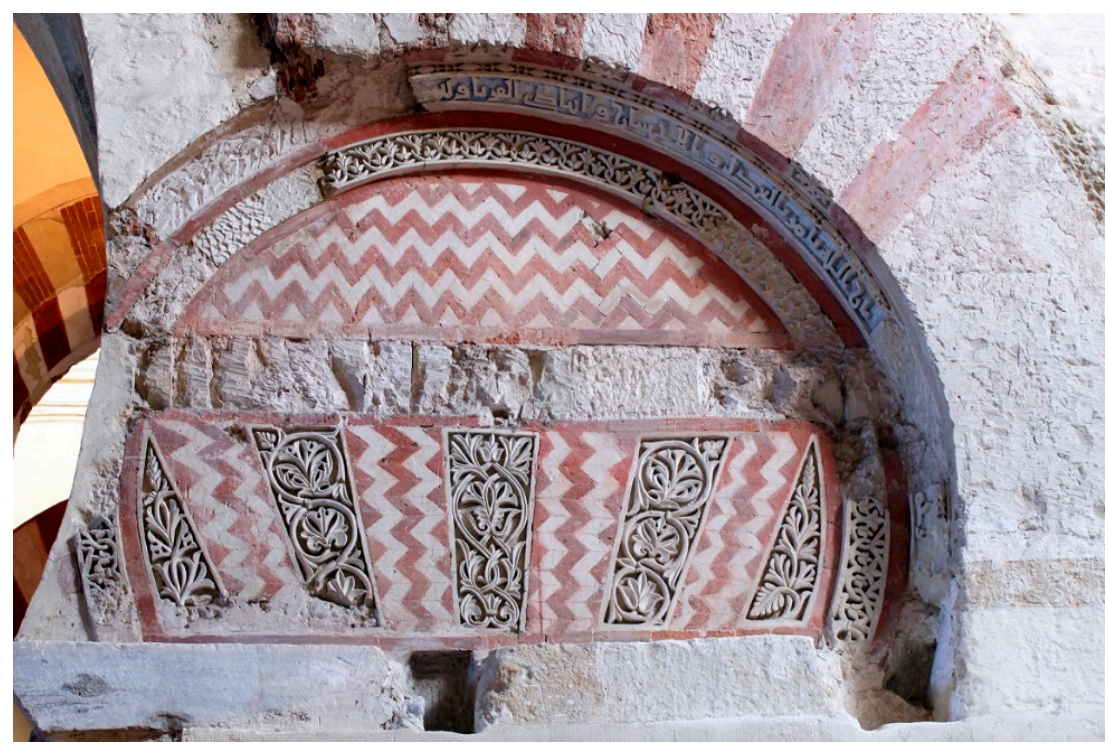

Figure 17. Great Mosque of Cordoba. Eastern door of the al-Hakam II's enlargement with traces of polychromy. (C) Photo took by author.

As Tabbaa (2001, pp. 53-54, 70-71) has argued in his studies on the semiotic interpretation of calligraphy, the form, accessibility, and readability of the monumental inscriptions are also part of the message. Moreover, the aesthetic values were linked with questions of status and power. Replacing

14 About the polychrome ceiling, see (Cabañero Subiza and Ontañón 2004). As for the lighting, there is little information about the lamps hanging from the ceiling: (Kider et al. 2009). 
floriated Kufic, used by Fatimids in public inscriptions, by cursive is understood by this author as the manner in which Sunnism rendered messages more clear and accessible, in contrast to the cryptic and esoteric character of shi'a inscriptions. Other scholars have a more nuanced view, like O'Kane (2018), who draws attention to the use of several styles like cursive and less ornate Kufic in some Fatimid monuments. In the case of Cordoba, we wonder whether the reason for choosing simple Kufic was also to facilitate diffusion of the caliphal messages. The different texts composed for the mosque were probably intended to make the ideological messages more direct and convincing, like khuṭba compositions, as well as to expand the reach of the message.

Finally, I would like to mention another singular epigraph (Figure 18). Little attention has hitherto been paid to the circular inscription located on the north face of the screen of arches delimiting the west bay of the maqșūra, that of the sābāt door:

The glory $\left(a l^{\prime} i z z a^{t}\right)$ and greatness (wa al-'az $\left.{ }^{\curvearrowright} a m a^{t}\right)$, and excellence (al-jaīrawat) and grandeur (al-kabīra) of God (li-llāh).

Two vegetal elements appear: a fleur-de-lis marking the beginning of the inscription, nearly on the axis of the word Allāh placed in the centre of the circle, and a half-palmette at the end of the vertical stroke of the "Z/ $/$ "ظ".

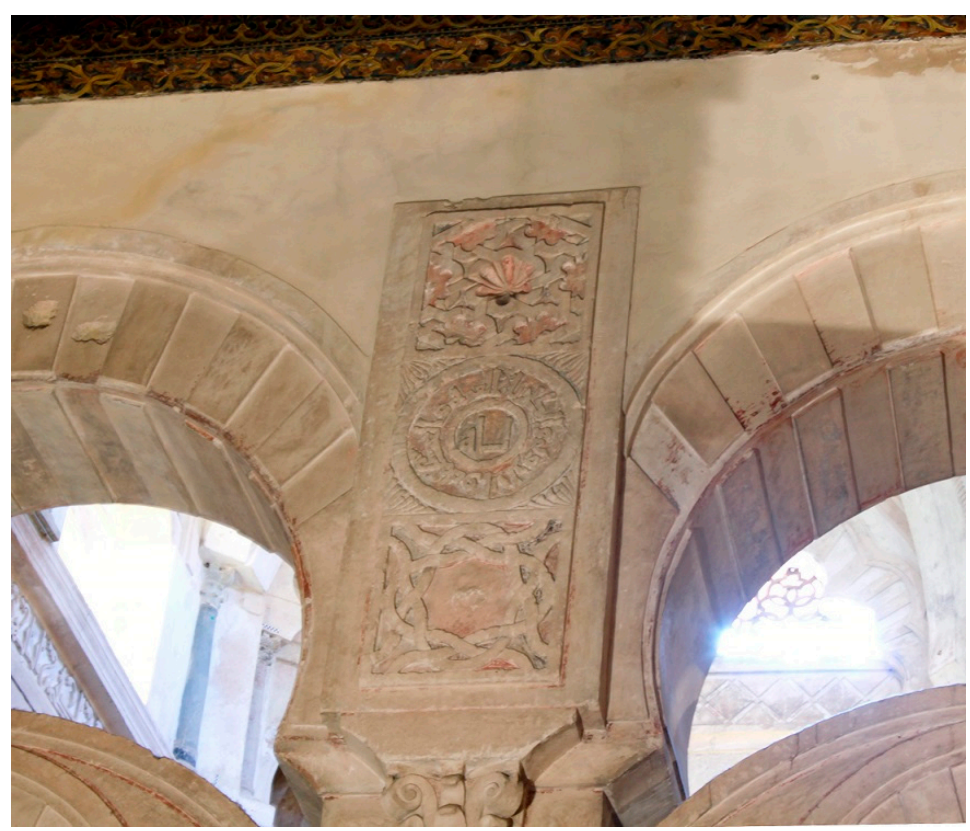

Figure 18. Great Mosque of Cordoba. Circular inscription located on the west bay of the maqșurra. (C) Photo took by author.

Monumental inscriptions in a circular format could be frequently found in Fatimid architecture, like those on the minarets of the Mosque of al-Hakim in Cairo, with the word Allah in the centre ${ }^{15}$. However, they are rare in al-Andalus; in fact, this is probably the earliest known example. Although it is not unlike the pattern of coins, the content of the inscription is different, since it speaks of divine qualities, as already seen.

15 Two circular roundels containing the word Allāh and a Quranic verse on its perimeter are on the northern minaret (early 11th century): O'Kane (2018, p. 145); Bierman (1998, p. 82). Another circular inscription, likely Fatimid, is decorating the mihrab façade of the great mosque of Qayrawan. 
According to M. Marín (2011, p. 284), Umayyads, aware of the propaganda power of inscriptions, used brief pious formulations such as quwwa illa bi-llāh, rabbu-na Alläh, al-'izza li-lläh ("there is no strength except in God", "God is our Lord", and "God is the glory"), which are similar to those of the circular inscription in the Great Mosque.

\section{Recipients and Ideologists of the Epigraphic Program}

As Grabar (1996, p. 68) said in his analysis of the Dome of the Rock: "There must have been a social, political or intellectual mechanism for the composition of the inscriptions and, therefore, for the conceptualization of the building's purpose", a mechanism that should imply "a learned and thoughtful individual or group chose to excerpt parts of a written, or more likely remembered Holy Text (the Quran) in order to formulate an iconophoric or aesthetic message about the building."

We can suppose that among the recipients of these messages inscribed on the walls of the prayer hall were the numerous and prestigious 'ulama and scholars teaching in the mosque, who would have been capable of understanding the complex nuances of the texts. The members of the Cordoban elites and the fuqah $\bar{a}$ would also have been able to read the epigraphs. They were precisely those who looked after the observance of religious dogmas and earthly laws.

For this reason, it can be assumed that the Māliki fuqaha and ulama closer to power were behind the theological discourse displayed in the dynastic great mosque. This religious elite was the caliphs' most effective instrument to exercise control over the people (the community of believers) and to respond to the theological and social issues posed by the appearance of heterodox schools of thought. This explains why Caliph al-Hakam II had often publicly demonstrated his support for the Māliki school, as pointed out in the decrees copied by Ibn Hayyān and other writers.

We do not know the name of the authors of the epigraphic program so far, but we may suspect that some important religious scholars like the qādī of Cordoba, Mundhir ibn Sa'îd al-Ballūtīi, might have participated (De Felipe and Lirola 2007, n' 1074; Fierro 2010, pp. 358-62). He was an honourable and erudite jurist with great prestige in the court of Abd Rahmān III and his son. From the year 950 until his death in 966, he was supreme judge of Cordoba and was part of the close entourage of al-Hakam II, on whom he had some influence. Mundhir took part in the meeting I mentioned at the beginning of this paper, in which the caliph decided to build the enlargement of the masjid al-jāmi'.

Andalusi writers pointed out his extraordinary qualities as a preacher and recalled his magnificent sermons (khuṭas) pronounced as khațīb of the great mosques of Madīnat al-Zahrā' and Cordoba. In fact, Mundhir was chosen to convince the people of Cordoba that the money used in the enlargement works was licit in origin. Al-Nubāhī said that Mundhir always found the most suitable Quranic verses for the subject he was dealing with to make his arguments more effective (Jones 2012, pp. 134, 247-49; Bourdieu 1975). That was exactly what the epigraphic program of the Great Mosque of Cordoba pursued: to make the content of the caliphal ideological message more effective.

Funding: This study is part of a project funded by the Spanish National I + D + i Plan (Research, Development and Innovation), HAR2013-45578-R.

Conflicts of Interest: The author declares no conflict of interest.

\section{References}

Abdeljaouad, Lofti. 2018. Le coufique des inscriptions monumentales et funéraires aghlabides. In The Aghlabids and Their Neighbors. Leiden: Brill. [CrossRef]

Al-Idrīsī, Al-Sharīf Abū ' Abd Allāh. 1949. Waçf al-Masjid al-Jami' bi-Qurt'uba: Description de la Grande Mosquée de Cordoue. Edited and Translated by Alfred Dessus-Lamare. Alger: Carbonel.

Al-Maqqarī, Ahmad Ibn-Muhammad. 1840. The History of the Mohammedan Dynasties in Spain Extracted from the Nafhu-t-tib min Ghosni-l-Andalusi-r-Rattib wa Tarikh Lisanu-d-Din Ibni-l-Khattib. Translated by Pascual de Gayangos. 2 vols. London: Oriental Translation Fund. 
Al-Maqqarī. 1967. Analectes sur L'histoire et la Littérature des Arabes d'Espagne. Edited and selection by Reinhardt G. Dozy, Gustave Dugat and William Wright. 2 vols. Amsterdam: Oriental Press.

Bierman, Irene. 1989. The Art of the Public Text: Medieval Islamic Rule. In World Art: Themes of Unity in Diversity. Edited by Irving Lavin. Pennsylvania: University Park and Pennsylvania State University Press.

Bierman, Irene. 1998. Writing Signs: The Fatimid Public Text. Berkeley: University of California Press.

Blair, Sheila, and Jonathan Bloom. 2006. Inscriptions in art and architecture. In The Cambridge Companion to the Qur'ān (Cambridge Companions to Religion). Edited by Jane Dammen McAuliffe. Cambridge: Cambridge University Press, pp. 163-78. [CrossRef]

Bloom, Jonathan M. 1983. The Mosque of al-Hakim in Cairo. Muqarnas I: 15-35. [CrossRef]

Bloom, Jonathan M. 1993. The Qubbat al-Khadra, and the iconography of height in Early Islamic Architecture. Ars Orientalis 23: 135-41.

Bloom, Jonathan M. 2015. Erasure and Memory: Aghlabid and Fatimid Inscriptions in North Africa. In Viewing Inscriptions in the Late Antique and Medieval World. Edited by Antony Eastmond. Cambridge: Cambridge University Press.

Bloom, Jonathan M., Ahmed Toufiq, Stefano Carboni, Antoine M. Wilmering, Jack Soultanian, Mark D. Minor, Andrew Zawacki, and Hbibi El Mostafa. 1998. Le Minbar de la Mosquée Kutubiyya. Nueva York: Metropolitan Museum.

Bourdieu, Pierre. 1975. Le langage autorisé. Note sur les conditions sociales de l'efficacité du discours rituel. Actes de la Recherche en Sciences Sociales 1: 183-90. [CrossRef]

Brisch, Klaus. 1959. Una nota marginal a la epigrafía árabe de la mezquita de Córdoba. Al-Andalus XXIV: 183-89.

Cabañero Subiza, Bernabé, and V. Herrera Ontañón. 2001. Nuevos datos para el estudio de la techumbre de la ampliación de al-Hakam II de la mezquita aljama de Córdoba: Cuestiones constructivas. Artigrama 16: 257-83.

Calvo Capilla, Susana. 2001. El programa epigráfico de la Mezquita de Córdoba en el siglo X: Un alegato a favor de la doctrina malikí. Qurtuba 5: 17-26.

Calvo Capilla, Susana. 2008. La ampliación califal de la mezquita de Cordoba: Mensajes, formas y funciones. Goya Revista de Arte 323: 89-106.

Calvo Capilla, Susana. 2010a. Justicia, misericordia y cristianismo: Una relectura de las inscripciones coránicas de la Mezquita de Córdoba en el siglo X. Al-Qanțara 31: 149-87. [CrossRef]

Calvo Capilla, Susana. 2010b. Analogies entre les Grandes Mosquées de Damas et Cordoue: Mythe et réalité. In Umayyad Legacies. Medieval Memories from Syria to Spain. Edited by Antoine Borrut and Paul M. Cobb. Leiden and Boston: E. J. Brill, pp. 281-311.

Calvo Capilla, Susana. 2014a. Las Mezquitas de Al-Andalus. Almería: Fundación Ibn Tufayl.

Calvo Capilla, Susana. 2014b. The Reuse of Classical Antiquity in the Palace of Madinnat al-Zahrā' and Its Role in the Construction of Caliphal Legitimacy. Muqarnas 31: 1-33.

Capilla, Susana. 2018a. Los espacios de conocimiento en el Islam: Mezquitas, Casas de la Sabiduría y Madrasas. In Domus Hispanica. El Real Colegio de España y el Cardenal Gil de Albornoz en la Historia del Arte. Edited by Manuel Parada López de Corselas. Bologna: Bononia University Press, pp. 179-94.

Calvo Capilla, Susana. 2018b. Peregrination and Ceremonial in the Almohad Mosque of Tinmal. In Encompassing the Sacred, Beiträge zur Islamischen Kunstgeschichte und Archäologie 7 (Ernst Herzfeld Society for Islamic Art and Archaeology). Edited by Lorenz Korn. Wiesbaden: Ludwig Reichert Verlag, forthcoming.

Creswell, Keppel Archibald Cameron. 1989. A Short Account of Early Muslim Architecture. Revised and Supplemented by James W. Allan. Cairo: The American University Press, pp. 358-373. First published 1985.

Cutler, Anthony, Jean-Michel Spieser, and Arietta Papaconstantinou. 1996. Byzance Médiévale 700-1204. Paris: Gallimard, pp. 185-90.

De la Puente, Cristina. 1999. The prayer upon the Prophet Muhammad (Tașliya): A manifestation of Islamic religiosity. Medieval Encounters 5: 121-29. [CrossRef]

Dessus-Lamare, Alfr. 1938. Le Muṣhaf de la Mosquée de Cordoue et son mobilier mécanique. Journal Asiatique 230: 551-75.

Dodds, Jerrilyn D. 1992. Al-Andalus: The Art of Islamic Spain. Madrid: Metropolitan Museum of Art, pp. 11-25.

Ewert, Christian. 1995. La mezquita de Córdoba: Santuario modelo del Occidente islámico. In La Arquitectura Islámica del Islam Occidental. Edited by R. López Guzmán. Granada: El Legado Andalusí, pp. 53-68. 
De Felipe, Helena, and Jorge Lirola. 2007. Ibn Sa'īd al-Ballūțī, Mundir. In Biblioteca de al-Andalus. Almería: Fundación Ibn Tufayl, vol. 5, p. n 1074.

Fernández Puertas, Antonio. 2015. The Mosque of Cordoba. Twentieth Century Archaeological Explorations. Granada: Universidad de Granada.

Fierro, María Isabel. 2007. The Mobile Minbar in Cordoba. How the Umayyads of al-Andalus Claimed the Inheritance of the Prophet. Jerusalem Studies in Arabic and Islam 33: 149-68.

Fierro, María Isabel. 2010. Mundhir ibn Sa'īd al-Ballūțī. In Christian-Muslim Relations. A Bibliographical History. (900-1050). Edited by David Thomas, Alexander Mallett and Barbara Roggema. Leiden: BRILL, vol. 2, pp. 358-62.

Flood, Finbarr Barry. 2001. The Great Mosque of Damascus: Studies on the Makings of an Umayyad Visual Culture. Boston: E. J. Brill.

García Sanjuán, Alejandro. 2008. Legalidad islámica y legitimidad política en el Califato de Córdoba: La proclamación de Hishām II. Al-Qanțara 29: 45-77. [CrossRef]

George, Alain. 2009. Calligraphy, Colour and Light in the Blue Quran. Journal of Quranic Studies 11: 75-125.

Grabar, Oleg. 1988. Notes sur le mihrab de la Grande Mosquée de Cordoue. In Le Mihrab Dans L'architecture et le Religion Musulmanes. Actes Colloque International. Edited by A. Papadopoulo. Leiden: Brill, pp. 115-22.

Grabar, Oleg. 1996. The Shape of the Holy: Early Islamic Jerusalem. Princeton: Princeton University Press.

Grabar, Oleg. 2006. The Dome of the Rock. Cambridge: Harvard University Press.

Hernández Giménez, Félix. 1928. Arte musulmán. La techumbre de la Gran Mezquita de Córdoba. Archivo Español de Arte y Arqueología 4: 191-225.

Hernández Giménez, Félix. 1959. El almimbar móvil del siglo X de la mezquita de Córdoba. Al-Andalus 24: 381-99.

Cabañero Subiza, Bernabé, and Valero Herrera Ontañón. 2004. La techumbre de la ampliación de al-Hakam II de la mezquita aljama de Córdoba. Análisis técnico y estudio formal de su policromía. Cuadernos de Madīnat al-Zahrā 5: 391-412.

Herzfeld, Ernst. 1912. Erster Vorläufiger Bericht uber die Ausgrabungen von Samarra. Berlin: Dietrich Reimer, p. 10.

Ibn, Hayyān, and Hayyān Halaf. 1965. Al-Muqtabis fi Ajbar Balad al-Andalus. Edited by 'Abd al-Rahman' Ali al-Hayyi. Beyrut: Dār Al-Taqāfä̈, vol. VII.

Ibn Hayyān, Hayyān ibn Ḥalaf. 1967. Anales palatinos del califa de Córdoba al-Hakam II. Translated by E. García Gómez. Madrid: Sociedad de Estudios y Publicaciones.

Johns, Jeremy. 2018. The Palermo Quran (ah 372/982-3 ce) and its Historical Context. In The Aghlabids and Their Neighbors. Leiden: Brill, pp. 587-610. [CrossRef]

Jones, Linda G. 2012. The Power of Oratory in the Medieval Muslim World. Cambridge: Cambridge University Press.

Khoury, Nuha NN. 1996. The Meaning of the Great Mosque of Cordoba in the tenth Century. Muqarnas 13: 86-88. [CrossRef]

Kider, Joseph T., Rebecca Fletcher, Nancy Yu, Renata Holod, Alan Chalmers, and Norman Badler. 2009. Recreating Early Islamic Glass Lamp Lighting. Paper presented at International Symposium on Virtual Reality, Archaeology and Cultural Heritage (VAST), Malta, September 22-25. [CrossRef]

König, Daniel G. Arabic-Islamic Views of the Latin West: Tracing the Emergence of Medieval Europe. Oxford: Oxford University Press.

Lamm, Carl Johan. 1927. Das Glas von Samarra, Die Ausgrabungen von Samarra IV. Forschungenzur Islamischen Kunst 2. Berlin: Dietrich Reimer/Ernst Vohsen.

Lammens, Henri. 1920. Le culte des bétyles et les processions religieuses chez les Arabes préislamites. Bulletin de l'Institut Français d'Archéologie Oriental XVII: 39-101.

Leisten, Thomas. 2003. Excavation of Samarra, v. I. Architecture: Final report of the first campaign 1910-1912. Mainz am Rhein: Verlag Philipp von Zabern.

Lévi-Provençal, Évariste, and Emilo García Gómez. 1950. Una Crónica Anónima de 'Abd al-Rahman III al-Nasir, (bilingual edition). Madrid: CSIC, Instituto Miguel Asín.

Marín, Manuela. 2011. Una galería de retratos reales: Los soberanos omeyas de al-Ándalus (siglos II/VIII-IV/X) en la cronística árabe. Anuario de Estudios Medievales 41: 273-90. [CrossRef]

Martínez Núñez, M. Antonia. 2015. Epigrafía monumental y élites sociales en al-Andalus. In Arqueología Medieval: Epigrafía árabe y Arqueología Medieval. Edited by Antonio Malpica and Bilal Sarr. Granada: Nakla, pp. 19-60.

Milwright, Marcus. 2015. The Dome of the Rock and Its Umayyad Mosaic Inscriptions. Edinburgh: Edinburgh University Press. 
Momplet Míguez, Antonio. 2012. De la fusión a la difusión en el arte de la Córdoba califal: La ampliación de al-Hakam II en la mezquita aljama. Anales de Historia del Arte 22: 237-58. [CrossRef]

Montasser, Dina. 2009. Modes of Utilizing Quranic Inscriptions on Cairene Mamluk Religious Monuments. In Creswell Photographs Re-Examined: New Perspectives on Islamic Architecture. Edited by Bernard O'Kane. Cairo: The American University in Cairo, pp. 187-218. [CrossRef]

Northedge, Alastair. 2005. The Historical Topography of Samarra. Samarra Studies I. London: British School of Archaeology in Iraq.

Ocaña Jiménez, Manuel. 1970. El Cúfico Hispano y su Evolución. Madrid: Instituto Hispano-Árabe de Cultura.

Ocaña Jiménez, Manuel. 1988. Inscripciones árabes fundacionales de la Mezquita-Catedral de Córdoba. Cuadernos de Madinnat al-Zahrā' 2: 9-28.

O'Kane, Bernard. 2018. Monumental Calligraphy in Fatimid Egypt Epigraphy in Stone, Stucco, and Wood. In The World of the Fatimids (Exhibition Catalogue). Edited by Assadullah Souren Melikian-Chirvani. Toronto: Hirmer Publishers, pp. 142-59.

Puerta, Vílchez, and José Miguel. 2013. Art and Aesthetics in the Work of Ibn Hazm of Cordoba. In Ibn Hazm of Cordoba. The Life and Works of a Controversial Thinker. Edited by Adang Camila, Maria Isabel Fierro and Sabine Schmidtke. Leiden: Brill, pp. 253-374.

Puerta Vílchez, José Miguel. 2007. La Aventura del Cálamo. Granada: Edilux.

Puerta, Vílchez, and José Miguel. 1997. Historia del Pensamiento Estético Árabe. Al-Andalus y la Estética Árabe Clásica. Madrid: Akal.

Ruiz Souza, Juan Carlos. 2001. La fachada luminosa de Al-Hakam II en la mezquita de Córdoba. Madrider Mittelungen 42: 432-46.

Swelim, Tarek. 2015. Ibn Tulun: His Lost City and Great Mosque. Cairo: The American University in Cairo Press.

Tabbaa, Yasser. 1991. The Transformation of Arabic Writing: Part I, Qur'ānic Calligraphy. Ars Orientalis 21: 119-48.

Tabbaa, Yasser. 2001. The Transformation of Islamic art during the Sunni Revival. Washington: University of Washington Press.

Van Ess, Josef. 1992. Abd al-Malik and the Dome of the Rock. An Analysis of Some Texts. In Bayt al-Maqdis: Abd al-Malik's Jerusalem. Edited by Julian Raby and Jeremy Johns. Oxford: Oxford University Press, pp. 89-103.

Zadeh, Travis. 2008. From Drops of Blood: Charisma and Political Legitimacy in the translatio of the 'Uthmānic Codex of al-Andalus. Journal of Arabic Literature 39: 321-46. [CrossRef]

(C) 2018 by the author. Licensee MDPI, Basel, Switzerland. This article is an open access article distributed under the terms and conditions of the Creative Commons Attribution (CC BY) license (http://creativecommons.org/licenses/by/4.0/). 